\title{
Pathobiology
}

\section{Skin Cancer: New Markers for Better Prevention}

\author{
Rüdiger Greinert \\ Dermatological Center, Klinikum Buxtehude, Elbe Kliniken, Buxtehude, Germany
}

\section{Key Words}

Skin cancer $\cdot$ Prevention • Molecular epidemiology •

Biomarker $\cdot$ Gene expression arrays $\cdot$ Epigenetic

biomarkers

\begin{abstract}
Skin cancer is the most frequent cancer in the white population worldwide. Incidence of basal cell carcinoma (BCC), squamous cell carcinoma (SCC) and malignant melanoma (MM) is still increasing. This trend can be counteracted by means of primary and secondary prevention because the main risk factor for skin cancer - UV-radiation - is known, and, early detected, skin cancer can be cured successfully. For early detection of skin cancer suitable risk (group) markers have to be used to identify persons at risk. In order to increase the sensitivity and specificity of early detection efforts (screening programs) new molecular markers or biomarkers should be used in the future in the field of molecular epidemiology. In this review the skin cancer problem is summarized and the possible use of new biomarkers for skin cancer development, progression, metastasis and prognosis is discussed. The review focuses on results of gene expression profiling using array techniques and the new possibilities for the use of epigenetic biomarkers.
\end{abstract}

Copyright $\odot 2009$ S. Karger AG, Base (c) 2009 S. Karger AG, Basel

$1015-2008 / 09 / 0762-0064 \$ 26.00 / 0$

Accessible online at:

www.karger.com/pat

\section{Introduction}

Skin cancer, in the sum of basal cell carcinoma (BCC), squamous cell carcinoma (SCC) and malignant melano$\mathrm{ma}(\mathrm{MM})$, is the most frequent cancer in the white population worldwide. Skin cancer incidence increases worldwide. This introduces a huge health problem in many countries and increases the financial burden on the health systems. However, the main risk factor for the induction of skin cancer is known: UV radiation. Furthermore, detected early, skin cancer is nearly $100 \%$ curable. These facts are the main reasons that skin cancer is highly preventable by means of primary prevention (avoidance of risk factors) or secondary prevention (early detection).

For early detection of skin cancer, it is necessary to use suitable risk (group) markers to identify persons early enough on their possible way to developing skin cancer. A number of markers are already known (such as skin type and number of nevi). However, the aim is to increase the sensitivity and specificity of early detection efforts (for example in screening programs) by the use of molecular markers or biomarkers in the field of molecular epidemiology.

This review, therefore, summarizes the skin cancer problem, introduces some criteria of molecular epidemiology and gives a short survey of new biomarkers for skin cancer development, progression and metastasis as well as for the use as prognostic markers. The review mainly describes the results of gene expression profiling using

E-Mail grein25@gmx.de 
array techniques (without going into technical details) to identify new biomarkers. Special attention is directed to the new, fascinating and important field of identification of epigenetic biomarkers for skin cancer development. The review likes to highlight the enormous potential of very promising examples of new techniques and scientific directions on hand, without any claim of completeness. Especially, the functionality of any new biomarker in practice, for example in the clinics or in intervention programs of primary prevention and in secondary prevention, cannot be discussed in detail because in most cases this has still to be tested in the future. However, where possible, indications for functionality will be given.

The review focuses on BCC, SCC and MM. Other forms of skin cancer like cutaneous $\mathrm{T}$ cell lymphoma, Karposi's sarcoma, Merkel cell carcinoma, sebaceous carcinoma, atypical fibroxanthoma and microcystic adnexal carcinoma comprise only about $1 \%$ of all forms of skin cancer and are, although important and serious diseases, mostly not dealt with in primary and secondary prevention of skin cancer.

\section{Epidemiology of Skin Cancer}

Three types of skin cancer, BCC, SCC and MM, sum up to the most frequent cancer worldwide. For MM, the incidence increases steeper than for any other type of cancer. Data for the nonmelanocytic skin cancers (NMSCs, BCC and SCC) show incidences in the range of $1,000,000$ new cases/year (USA, 2005) [1] and about 100,000 new cases/year (Germany, 2003) [2]. Eighty percent of these are found on sun-exposed areas of the human body [3].

Corresponding numbers for MM (the most deadly skin cancer, $20-25 \%$ of diagnosed patients die) are about 62,000 new cases/year (USA, 2006) [4] and about 15,000 (Germany, 2004; Robert-Koch-Institut: http:// www.rki.de). Most melanoma occur on sun-exposed areas of the body. Estimated 10-year survival rates for patients without evident metastases range from $88 \%$ for those patients with tumors $\leq 1 \mathrm{~mm}$ without ulceration to $32 \%$ for those patients with tumors $>4 \mathrm{~mm}$ with ulceration [5].

Skin cancer incidence is still increasing in most countries $[6,7]$, although some stabilization has been observed for parts of Western Europe and Scandinavia [7, 8]. Nevertheless, being the most frequent cancer, skin cancer represents a huge problem for the public. The personal, medical, clinical and, last but not least, financial burden of skin cancer has therefore to be reduced by means of primary prevention and early detection.

\section{Environmental Risk Factor(s)}

Although environmental arsenic exposure [9] or certain types of human papillomaviruses (as cofactors in association with UV) [10] have been considered to play a role during the pathogenesis of NMSC, the overwhelming number of epidemiological and experimental investigations recognized UV radiation as the main environmental risk factor [11-16]. The role of UV radiation in melanomagenesis has been discussed in the past decades, because MM etiology also strongly depends on genetic predispositions (for example, allelic variances in the melanocortin 1 receptor) [17]. However, recent epidemiological and experimental investigations, which are mainly dealing with UV-associated induction of benign nevi and the UV-induced mutation patterns, for example in the $B R A F$ - gene (in nevi), clearly underline once more the important role of UV radiation as a risk factor for $\mathrm{MM}$ $[11,18-22]$. It is furthermore important to consider that different types of skin cancer have a different dependence on UV exposure patterns. Whereas MMs are mainly induced by intermittent UV exposure (such as sunburns) $[11,18,20]$, SCC induction is highly dependent on cumulative UV exposure. BCC induction depends on cumulative as well as intermittent exposure patterns [11].

Because the main environmental risk factor in the etiology of skin cancer, UV radiation [regardless of its natural (sun) or artificial (sunbeds) origin], is known, skin cancer is one of the key cancers which can be prevented by means of primary prevention (avoiding, reducing risk; see Prevention and Early Detection).

\section{Etiology of Skin Cancer}

In recent years a huge amount of information has been collected in the fields of genetics, molecular pathways and cellular changes which are important players in skin cancer induction, promotion, progression and metastasis. There is not enough space in this review to deal with these topics in detail. However, excellent reviews exist and selected examples can be found in the reference list [23-30].

Very briefly summarized, there is convincing evidence that BCC etiology is highly dependent on dysregula- 
tion of the hedgehog signaling pathway, whereas for SCC etiology, p53-regulated pathways are of outstanding importance. For MM, at least 3 molecular pathways have been found to be nearly invariably dysregulated in melanocytic tumors, including the RAS-RAFMEK-ERK pathway (through mutation of BRAF, NRAS or KIT), the p16 INK4A-CDK4-RB pathway (through mutation of INK4A or CDK4) and the ARF-p53 pathway (through mutation of $A R F$ or TP53). Less frequently targeted pathways include the PI3K-AKT pathway (through mutation of NRAS, PTEN or PIK3CA) and the canonical Wnt signaling pathway (through mutation of CTNNB1 or $A P C)$ [31].

It is to be expected that future research, dealing with biological markers, will give further insight into the etiology of skin cancer. Very recent findings in the field of stem cell research furthermore show very clearly that epidermal stem cells and their uncontrolled regulation on the genetic and epigenetic level, are the main cell targets involved in skin carcinogenesis [31-37]. Investigating the genetic and epigenetic regulation of (cancer) stem cell fate, therefore, will enduringly increase our knowledge about etiology as well as about (bio-)markers indicative for progression, staging and metastasis of skin cancers (see Epigenetic Markers for Molecular Epidemiology of Skin Cancer).

\section{Prevention and Early Detection}

Because UV radiation is known as the main risk factor for development of skin cancer and because it is known that early stages of skin cancer can be cured with good prognosis, skin cancer is the ideal cancer to be combated by means of primary and secondary prevention (early detection) as well as tertiary prevention, which already includes therapy and rehabilitation. Primary prevention of skin cancer can be achieved by continuously informing and educating the public about the risks of UV exposure. This is done, for example, in huge information campaigns like the 'Slip (on a shirt), Slop (on some sunscreen), Slap (on a hat)' initiative and the following SunSmart campaign in Australia (http://www.sunsmart.com.au) or the periods of live program (POLP) in Germany [38, 39], which provide certain age groups as well as their caretakers like parents, kindergarten teachers, teachers and physicians with special adapted information about a responsible exposure to UV radiation to avoid skin cancer risk.

Secondary prevention of skin cancer deals with early detection of skin cancer or precancerous lesions in order to find early stages of the malignancy which can be cured with good prognosis. This can be done in screening campaigns, either in form of a mass screening (as performed at the moment in Germany), as a risk group screening or as combinations of these.

Risk groups for NMSCs are known, for example, persons with skin type I, persons suffering from actinic keratosis (AK, the precancerous lesion of SCCs) or those which already were diagnosed for BCC or SCC. Persons at risk for MM are those with skin type I, with an MM in their own or family history, with high numbers of melanocytic nevi, with clinical atypical nevi or with congenital nevi [40-42].

Although these risk group markers are already quite specific, it is the aim to increase the specificity and sensitivity of early detection programs (screening) by the use of more objective molecular markers or biomarkers. This might be even more important if one uses these biomarkers to identify early stage in development, progression and metastasis of skin tumors or for clinical prognosis. At his point, methods of molecular epidemiology come into play.

\section{Molecular Epidemiology and Biomarkers}

Traditional epidemiology tries to identify environmental and/or lifestyle factors that increase or reduce the risk of specific diseases, especially cancer [43]. This has long been performed in a kind of a black box approach where certain exposures have been correlated with, for example, certain cancer outcomes without knowing much about the reactions and processes (the main components of the black box) between exposure and cancer. Nevertheless, traditional epidemiology has been used for a long time to cast some light into the black box in order to find some biologic plausibility as an important criterion to assign causality [43]. However, this has often been done by extensive use of questionnaires and interviewbased approaches in order to find at least associations of a certain exposure with a certain type of cancer. Yet, these methods are often biased by subjective failures to remember exact time points of appearance of, for example, preclinical symptoms of a disease, individual behavior in the environment and other individual components of life style. Especially the difficulties in an accurate, mostly retrospective determination of personal exposure (patterns) limit our ability to find an objectively determined connection between exposure, lifestyle and cancer. This also limits a more detailed knowledge about the 
Table 1. Examples different classes of biomarkers in skin cancer

\begin{tabular}{|c|c|c|c|}
\hline \multirow[t]{3}{*}{ Class of biomarker } & \multicolumn{3}{|l|}{ Example for skin cancer } \\
\hline & \multicolumn{2}{|l|}{ NMSC } & \multirow[t]{2}{*}{ MM } \\
\hline & BCC & SCC & \\
\hline Exposure markers & erythema & erythema & $\begin{array}{l}\text { erythema, number of UV-induced } \\
\text { nevi in childhood }\end{array}$ \\
\hline Marker of internal dose & $\begin{array}{l}\text { erythema, number of CPDs induced } \\
\text { in DNA of keratinocytes }\end{array}$ & $\begin{array}{l}\text { erythema, number of CPDs induced } \\
\text { in DNA of keratinocytes }\end{array}$ & $\begin{array}{l}\text { erythema, number of CPDs induced } \\
\text { in DNA of melanocytes }\end{array}$ \\
\hline $\begin{array}{l}\text { Markers of biologically } \\
\text { effective dose }\end{array}$ & $\begin{array}{l}\text { detection of UV-specific signature } \\
\text { mutations, persistent UV-induced } \\
\text { DNA damage }\end{array}$ & $\begin{array}{l}\text { detection of UV-specific signature } \\
\text { mutations, persistent UV-induced } \\
\text { DNA damage }\end{array}$ & $\begin{array}{l}\text { detection of UV-specific signature } \\
\text { mutations, persistent UV-induced } \\
\text { DNA damage }\end{array}$ \\
\hline $\begin{array}{l}\text { Markers of altered structure/ } \\
\text { function }\end{array}$ & $\begin{array}{l}\text { e.g. UV-induced chromosome } \\
\text { aberrations }\end{array}$ & $\begin{array}{l}\text { e.g. UV-induced chromosome } \\
\text { aberrations }\end{array}$ & $\begin{array}{l}\text { e.g. UV-induced chromosome } \\
\text { aberrations }\end{array}$ \\
\hline Markers of susceptibility & $\begin{array}{l}\text { skin type, e.g. heritable mutations } \\
\text { in } P T C H \text { gene }\end{array}$ & $\begin{array}{l}\text { skin type, e.g. heritable mutations in } \\
X P \text { genes }\end{array}$ & $\begin{array}{l}\text { skin type, e.g. heritable mutations in } \\
C D K N 2 A \text { and } C D K 4 \text { genes }\end{array}$ \\
\hline $\begin{array}{l}\text { Markers for diagnostics, } \\
\text { prognosis, progression and } \\
\text { metastasis }\end{array}$ & $\begin{array}{l}\text { changes in gene expression, mutations } \\
\text { in (tumor suppressor) genes, e.g. } \\
\text { differential expression of genes in } \\
\text { hedgehog-, WNT- or MAPK signaling, } \\
\text { e.g. promoter hypermethylation of } \\
\text { CDH1 }{ }^{1}\end{array}$ & $\begin{array}{l}\text { changes in gene expression, mutations } \\
\text { in (tumor suppressor) genes, e.g. } \\
\text { differential expression of GADD } 45 \\
\text { genes in MAPK signaling, e.g. } \\
\text { promoter hypermethylation of } C D H 1^{1}\end{array}$ & $\begin{array}{l}\text { changes in gene expression, mutations } \\
\text { in (tumor suppressor) genes, e.g. } \\
\text { differential expression of } N O T C H-2 \text {, } \\
C D K N 1 A, D D B 2 \text {, DNMT1 or } \\
\text { HDAC1-HDAC3, e.g. promoter } \\
\text { hypermethylation of } C D H 1 \text { or } \\
C D K N 2 A^{1}\end{array}$ \\
\hline
\end{tabular}

${ }^{1}$ For more information, see text.

etiology of many kinds of cancer which is needed to be used as a basis for cancer prevention strategies [43].

The use of new molecular markers as well as the use of new methods in molecular epidemiology will help us to objectify our knowledge on reasons responsible for cancer induction, promotion and progression as well as processes involved between exposure and appearance of cancer. This, in turn, will lead to an important contribution of molecular (cancer) epidemiology to a better understanding of cancer etiology, which will yield a better scientific basis for strategies to be used in primary and secondary prevention of cancer.

Molecular epidemiology assesses the biological basis for an association between an environmental carcinogen and the occurrence of cancer by using biological markers (biomarkers) to assess exposure, internal dose, biological effective dose, altered structure/function, invasive cancer diagnosis, tumor metastasis and prognosis as well as susceptibility [43]. This can be visualized by the scheme shown in figure 1.

According to a definition given by the International Agency for Research on Cancer, the term biomarker refers to indicators of exposure and/or events in biological systems or samples. However, there is no strict boundary between different classes of markers, and several markers can be considered to belong to more than one class. It is also possible that a certain biomarker is composed of several molecular events which only in the sum of their actions might have some predictive value. Furthermore, a very important issue when dealing with new biomarkers is the test of their functionality. New technologies like high-throughput array techniques give only first hints about the possible use of new biomarkers, which then have to be tested under practical conditions.

Table 1 summarizes examples for classes of biomarkers which might be used in the field of skin cancer (see Examples for Biomarkers in Skin Cancer). It shows a number of already known biomarkers (such as erythema and CDKN2A mutation) as well as examples of new possible biomarkers (see Epigenetic Markers for Molecular Epidemiology of Skin Cancer).

\section{Examples for Biomarkers in Skin Cancer}

Several classical biomarkers have already been used in the field of skin cancer which fit into the categories summarized in table 1 (see Exposure Markers to Markers of 
Fig. 1. Difference between traditional and molecular epidemiology (adapted from Chen [43]).

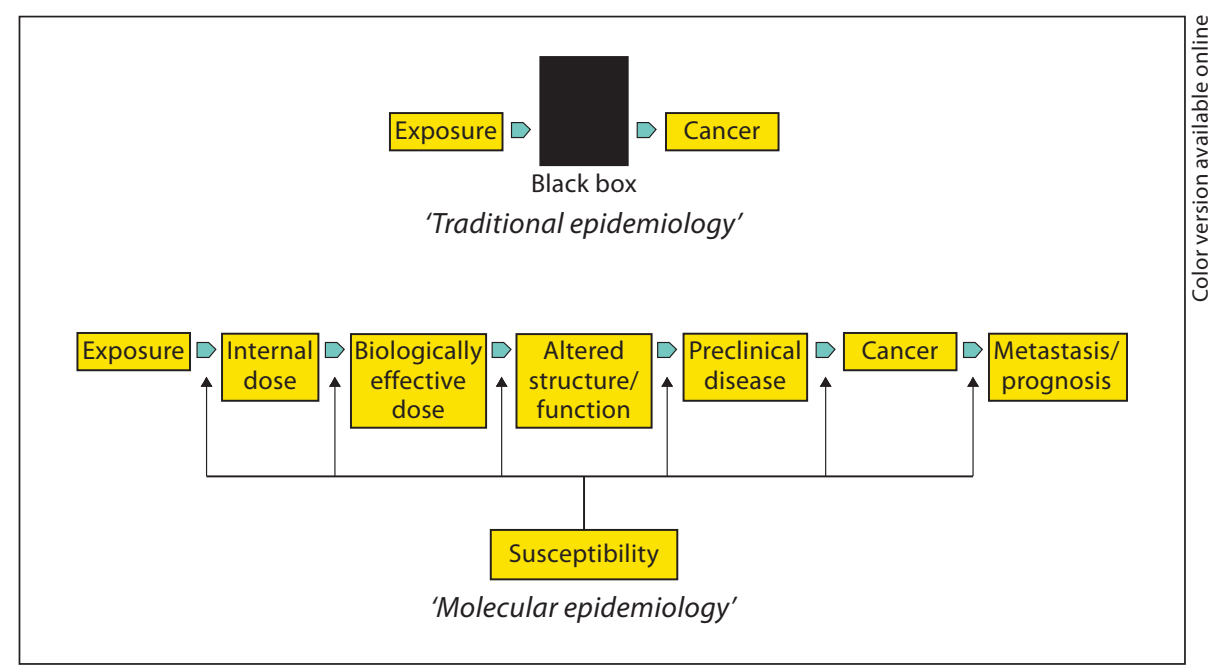

Susceptibility). However, these markers are mainly markers to identify persons at risk and, therefore, important for primary prevention. They are poor biomarkers for cancer diagnostics, progression, prognosis and metastasis, factors which are of main interest in secondary prevention, that is, early detection of skin cancer (see Molecular Markers to Characterize the Transition from 'Normal' to Cancer Cells: Use as Markers in Cancer Diagnostics, Progression, Prognosis and Metastasis).

\section{Exposure Markers}

\section{Erythema}

Many dermatological studies have proven that mainly UVB irradiation causes DNA damage which activates inflammatory processes leading to erythema of the skin. A mean minimal erythemal dose (MED) has been determined, from a large number of individual measurements, for humans belonging to skin type II. The value of $1 \mathrm{MED}$ corresponds to $210 \mathrm{~J} / \mathrm{m}^{2}$. The time to reach MED is UV irradiance dependent. For example at UV indices of 2, 4 and 8 (which represent erythemically weighted measurements of increasing solar UV irradiance), the MED is reached at 100, 50 and $25 \mathrm{~min}$, respectively. Erythema might be seen as a good example for a biomarker belonging to different classes, that is, it could serve as a marker of exposure as well as of internal dose (table 1).

\section{Number of UV-Induced Benign Nevi in Childhood}

Benign UV-induced nevi are one of the main risk factors for the development of MM. A dependence of the number of nevi on intermittent UV exposures (such as sunburns) has been demonstrated in a number of investigations [44-50]. Recent work furthermore shows that UV-induced formation of melanocytic nevi takes place already in early childhood [18] and that induction is possible at suberythemal [18] UV doses in the case of certain genetic predispositions [51]. In a huge meta-analysis, Gandini et al. [40] were able to show that the increased number of UV-induced nevi (120 vs. $<15)$ increased the (pooled) relative risk for development of MM by a factor of nearly 7. These results clearly add further evidence to the prominent role of UV radiation in melanoma development.

\section{Marker of Internal Dose}

\section{Induction of Cyclobutane Pyrimidine Dimers in DNA}

of UV-Exposed Skin Cells

UV photon absorption by DNA leads to photochemical conversion of absorbed energy into photodimerization between adjacent pyrimidine bases. According to an action spectrum, UVB is about 1,000 times more effective than UVA to induce this kind of photodimerization [52]. Photodimerizations between adjacent pyrimidine bases are by far the most prevalent photoreactions resulting from the direct action of UV radiation. Two major photoproducts are formed via this reaction pathway: the cyclobutane pyrimidine dimer (CPD) and the pyrimidine(6-4)pyrimidone photoproduct (6-4PP). However, using the same wavelength of excitation in the UVB, 6$4 \mathrm{PPs}$ are induced only at $15-30 \%$ the rate of CPDs [53]. 
Using fluorescently labeled monoclonal antibodies against CPD and a calibration with a radioimmuno assay [52], it was recently shown that a UVB dose of $300 \mathrm{~J} / \mathrm{m}^{2}$ is able to induce several hundred thousands of CPDs per genome per cell [54]. Induction of CPDs is UV dose dependent as well as the repair of these lesions via nucleotide-excision repair (NER). Increasing the UV(B) dose and the amount of premutagenic CPDs leads to an increase in the time constant for NER to remove CDPs [54, 55]. Furthermore, deficiencies in NER of CPDs have been linked with increased risk of cutaneous MM and NMSCs [55-57].

Therefore, measurements of induction and of repair characteristics of CPDs represent a useful biomarker of internal dose.

\section{Markers of Biologically Effective Dose}

\section{Signature Mutations}

When CPDs are not repaired, these DNA lesions can lead to mutations in the DNA sequence. Mutations in the form of $\mathrm{C} \rightarrow \mathrm{T}$ and $\mathrm{CC} \rightarrow \mathrm{TT}$ transitions are known as $\mathrm{UV}$ signature mutations [58-61]. These mutations have long been believed to be a specific signature for UVB radiation. However, recent work points into the direction that also UVA induces CPDs which lead to UV signature mutations [62-64].

UV signature mutations have been detected in a number of tumor suppressor genes and oncogenes (including, for example, patched, p16, ras and p53) in human SCC, BCC and MM [65]. Because the important biological function of $\mathrm{p} 53$ results from transcriptional activation of a large number of genes involved in fundamental cellular processes like cell cycle control, apoptosis, DNA replication, repair, genome instability and senescence, it is not surprising that genetic alterations of the p53 gene have most frequently been found in human tumors [66] and especially in skin cancers like SCC, BCC and precancerous actinic keratoses [67-71]. Convincing models for the initial steps of UV carcinogenesis, especially for SCC, already exist $[72,73]$, based on findings that $\mathrm{p} 53$ mutations in nonmelanoma skin cancers are detected at higher frequency (50-90\%) than those in internal malignancy and that the predominant alterations are $\mathrm{C} \rightarrow \mathrm{T}$ and $\mathrm{CC} \rightarrow \mathrm{TT}$ transitions at dipyrimidine sites [67].

\section{Persistent UV-Induced DNA Damage}

Mitchell et al. [74] exposed Skh-1 hairless mice with suberythemal doses of chronic UVB for 40 days and ana- lyzed the amount and distribution of CPDs. It could be shown that CPDs accumulated as a result of chronic irradiation and that the damage persisted in the epidermis and the dermis over several weeks. While these persistent CPDs were evenly distributed in the dermis, we found a small number of heavily damaged cells in the basal layer of the epidermis up to 50 days after the chronic treatment. CPD-retaining basal cells (CRBCs) are not apoptotic and disappeared when the skin cells were induced to proliferate by treatment with a tumor promotor or a sunburn dose of UVB $[74,75]$. At the same time, a slight increase in p53-mutated cell clones was found in the skin. In a following study it could then be shown that the occurrence of CRBCs is not limited to mouse skin, since similar heavily damaged cells were found in human skin [75], even more then 6 weeks after in vivo irradiation.

Since it has been shown that a small number of mouse skin cells which possess low proliferation activity and retain certain labels (BrdU) as well as DNA damage are epidermal stem cells [76-79], the occurrence of CRBCs in skin suggests that these persisting cells are epidermal stem cells. These results are supported by very recent findings in the mouse skin cancer model [80]. We investigated the correlation between CRBCs in human skin and sun exposure history by quantifying CRBCs in skin biopsies taken from parts of the body with different sun exposure histories. A good correlation between sun exposure of skin areas where the biopsies had been taken from and the number of CRBCs in the basal layer of epidermis could be documented [Greinert et al., submitted].

These findings suggest that the CRBCs which are observed in mouse and human epidermis are very likely epidermal stem cells which could function as progenitors of skin cancer (stem) cells. The genetic and epigenetic regulatory pathways which are involved in this stem cell-related skin cancer model are currently under investigation. Regardless of the model, CRBCs might be used as a biomarker for assessing skin cancer risk in a human population exposed to UV radiation.

\section{Markers of Altered Structure/Function}

\section{Chromosome Aberration}

BCC and SCC frequently show losses of chromosomal fragments, leading to, for example, losses of heterozygozity $(\mathrm{LOH})$ [81]. In BCCs, $\mathrm{LOH}$ is mostly restricted to chromosome arm 9q, whereas LOH in SCCs is found in a larger group of chromosomal positions, including $3 \mathrm{p}$, $9 \mathrm{p}, 13,17 \mathrm{p}$ and 17q [13]. The human homolog of the Dro- 
sophila patched gene (PTCH), located at chromosome $9 \mathrm{q} 22.3$, is frequently altered in both nevoid BCC syndrome and sporadic BCCs. Danaee et al. [82] also studied alterations of the PTCH gene locus in SCC. They analyzed $\mathrm{LOH}$ at 5 markers in and around the PTCH gene in 276 keratinocyte tumors and found a high prevalence of a LOH at 9q22.3 in both BCC (75.5\%) and SCC (60.8\%). Specifically, the PTCH gene was lost in $60 \%$ of BCC and $50 \%$ of SCC tumors. Among SCC tumors, 9 q22 LOH was significantly more likely to occur in those who tend to burn $(\mathrm{p}<0.05)$, and this association was strongest for tumors that occurred on sun-exposed areas of the body $(p<0.04)$. Additionally, 9q22 LOH occurred more frequently in SCC tumors associated with a history of severe sunburns $(\mathrm{p}<0.08)$. Overall, these data support the hypothesis that loss of $\mathrm{PTCH}$ is a common, early lesion for SCC and BCC [82], and that chromosomal alterations in certain gene loci might be used as biomarker for UV (sun) exposure in the past [for example, if they appear in persisting epidermal (stem) cells].

Chromosome alterations are also found in MM. LOH at 9p21 (the locus of the CDKN2A (p16INK4a) gene) is linked with both familial and sporadic melanoma $[13,84]$ and has been linked with early steps in melanoma development [84].

\section{Markers of Susceptibility}

\section{Skin Type}

Skin type is the classical hereditable susceptibility marker which renders persons with a certain skin type (pigmentation type) more or less sensitive to UV radiation and UV-induced skin damage, for example, erythema. Human skins have constitutionally different solar sensitivities, depending on the amount and quality of melanins which are produced in epidermal melanocytes. For the purpose of evaluation of skin sensitivity, specific skin types, ranging from type I (no tanning, melanocompromised) to type VI (black skin, melanoprotected), have been defined. In the basic meta-analysis of Gandini et al. [40], it has been analyzed that the relative risk to suffer from $\mathrm{MM}$ is, for example, 2 -fold increased for skin type I compared to skin type IV.

\section{Heritable Mutations}

Gene mutations in special genes, which are hereditable and render their carriers more susceptible to skin cancer in any phase of its development, are of great importance to understand the etiology of skin cancer and to identify persons at risk as early as possible during primary and secondary prevention of skin cancer. A number of genes have already been described.

XP genes, which are responsible for essential steps in nucleotide excision repair, NER, are mutated in patients suffering from xeroderma pigmentosum, whose risk to develop skin cancer is more than 1,000 -fold increased [85].

Patients suffering from the nevoid basal-cell carcinoma syndrome show heritable mutations in the tumor suppressor gene patched (PTCH). PTCH was cloned from the locus for nevoid basal-cell carcinoma syndrome. It was shown afterwards that a large portion of sporadic BCCs also carries PTCH mutations and leads to the discovery of the importance of the sonic hedgehog signaling pathway for developing BCCs [86-88].

An important risk factor for MM is a positive family history of melanoma. Family cases, however, constitute only a small portion (1-2\%) of all cutaneous melanoma [89]. In these families, melanoma susceptibility is enhanced by mutation in the cyclin-dependent kinase inhibitor gene CDKN2A and the cyclin-dependent kinase $\mathrm{CDK} 4$ gene. These genes have been shown to confer elevated risk in $20-40 \%$ of melanoma-prone families [89]. CDKN2A codes for 2 important tumor suppressors (p16INK4A and p14ARF), which play important roles in cell cycle control and apoptosis, and mutations in CDKN2A impair the function of both p53 and pRB pathways [90], indicating that these mutations are important for many cancers including nonfamilial MM [91]. Gandini et al. [40] evaluated in their meta-analysis a relative risk of 1.74, for persons belonging to families with a history of MM compared to control families (see Molecular Markers to Characterize the Transition from 'Normal' to Cancer Cells: Use as Markers in Cancer Diagnostics, Progression, Prognosis and Metastasis as well as Epigenetic Markers for Molecular Epidemiology of Skin Cancer).

\section{Molecular Markers to Characterize the Transition from 'Normal' to Cancer Cells: Use as Markers in Cancer Diagnostics, Progression, Prognosis and Metastasis}

Certain special molecular markers have been described in the past which might be able to characterize different stages in melanoma development and progression. For example [for a recent review, see Utikal et al. 92], the melanoma inhibitory activity (MIA) protein, which is strongly expressed in melanoma cells but not in melanocytes, rep- 
resents a key molecule regulating melanoma progression $[93,94]$. MIA has been shown to interact with fibronectin and integrins, thereby inhibiting cell-matrix contacts and enabling cells to migrate and invade other tissues which may provide a mechanistic explanation for the role of MIA in metastasis [94]. However, MIA is not only a progression marker. Its role in melanoma development has also been well documented. It was shown, for example, that MIA regulates the expression of transcriptional regulators like MITF and PAX3 which are known to play an important role in melanoma development $[95,96]$.

Phosphorylated signal transducers and activator of transcription (pSTAT1, pSTAT3) have recently been reported to function as another important potential biomarker of melanocytic transformation and progression. It has been shown that STAT3 is constitutively activated in melanoma and the pSTAT1/pSTAT3 ratio has been evaluated as a potential prognostic index, with higher PSTAT1/ pSTAT3 ratios in tumor tissue predicting improved overall survival of patients [97]. Furthermore, in a prospective trail, the correlation between pSTAT3 expression and the severity of histopathological atypia and architectural disorder in atypical nevi, which are a prominent risk factor for MM [40], has been studied [98]. According to cytomorphology, atypical nevi were grouped into 3 categories [99-101]: mild, moderate and severe atypia. Taking this kind of classification, Wang et al. [98] were able to show that the baseline expression level of pSTAT3 is positively associated with the degree of atypia in nevi $[98,101]$. The possibility to discriminate between different types of atypia of nevi via the baseline expression level of pSTAT3 seems to indicate that pSTAT3 is a biomarker with sufficient functionality for practical approaches.

These are only 2 examples, which already show that molecular staging of melanoma might be possible on a molecular level, but further research is needed to show which molecular markers might be suitable to function as risk, progression and prognostic molecular markers of MM and of other skin cancers in the future. Finding those markers will surely be facilitated by further straightforward use of high-throughput array techniques in order to give a first orientation to find biomarkers which can be used in primary and secondary prevention of skin cancer.

\section{Results from the Use of Array Techniques}

\section{Melanoma}

A number of groups have already looked for up- and downregulation of genes in melanoma compared with healthy cells and tissues using relatively small-size expression arrays [102-107]. The results of this studies disagree largely. This has been explained by the use of small platforms, few replicates and insufficient statistical stringency [108]. A systematic analysis of 3 studies [109-111] using larger arrays showed that each study identified putative molecular transformation markers, but only 2 differentially expressed genes (CITED1 and $C D H 3$ ) could be identified in common by all groups [110]. This is a remarkably low yield for highly sophisticated array techniques.

However, Hoek et al. [110] recently performed an analysis that shows that DNA microarray programs of sufficient scope may identify, with high reproducibility, a large number of genes whose expression are changed significantly in melanoma. The analysis shows 86 genes which undergo significant and reproducible downregulation in melanoma cells. Furthermore, the top 150 genes (from a total of 1,610) which undergo significant and reproducible upregulation in melanoma are listed. These genes involve a number of factors well known in melanoma research, such as the downregulation of epithelial cadherin, dipeptidyl peptidase IV and c-Kit or the upregulation of known melanoma antigens (MAGEA6, MAGEA3, MAGEA12 and PRAME), neurological cadherin and osteopontin. In addition, the upregulation of the Notch-2 gene seems to confirm earlier findings showing the Notch signal pathway to be one of the main drivers in melanoma transformation [110]. However, less familiar changes in gene expression are also found, such as the downregulation of a putative tumor suppressor (WAP 4-disulfide core domain 1, WFDC1) or the upregulation of tumor protein D52 (TPD52), which have not been associated with MM until now. It is interesting to note that the above-mentioned studies do not report significant changes in expression of genes, which are known from a variety of molecular genetic investigations to be important for the etiology of melanoma, for example CDKN2A (p16/INK4a, p14/p19ARF) and BRAF, genes for DNA repair processes like the XP gene family involved in NER, genes responsible for cell cycle control like cyclin-dependent kinases (CDK2, CDK4, CDK6) or genes involved in apoptosis (BAX, FAS, CASP). This might indicate that more than expected and even unknown candidate genes might be involved in melanomagenesis, which have to be tested for their functionality to serve as biomarkers.

Recently, however, it could be shown that defective cell cycle checkpoint functions in melanoma are associated with altered patterns of gene expression [112]. Defects in DNA damage response may cause genetic instability and 
malignant progression in melanoma. Because DNA double-strand breaks appear to be a feature of early and late stages of melanomagenesis $[113,114]$, ionizing radiation was used to induce DNA double-strand breaks in normal human melanocytes, melanoma cell lines and DNA damage checkpoints acting in the $G_{1}$ and $G_{2}$ phase of the cell cycle were analyzed [112]. It turned out that normal human melanocytes displayed effective $G_{1}$ and $G_{2}$ checkpoint response. The majority of melanoma cell lines (11/16), however, displayed a significant defect in 1 or both checkpoints. Melanomas with BRAF mutations displayed a defect in DNA damage $G_{2}$ checkpoint function. In contrast the epithelial-like subtype of melanomas with wild-type NRAS and BRAF displayed an effective $\mathrm{G}_{2}$ checkpoint but a significant defect in $\mathrm{G}_{1}$ checkpoint function. Using a 44,000-element human genome 60 -mer oligonucleotide microarray, it could furthermore be shown by RNA expression profiling that melanoma cell lines with defects in DNA damage $\mathrm{G}_{1}$ checkpoint displayed reduced expression of p53 transcriptional targets, such as $C D K N 1 A$ and $D D B 2$, and enhanced expression of proliferation-associated genes, such as CDC7 and GEMININ. It is interesting to remember that the CDKN1A gene product, $\mathrm{p} 21^{\text {Waf1 }}$, is a tumor suppressor with important functions in cell cycle control [30]. On the other hand, germline inactivation of DDB2 in humans causes xeroderma pigmentosum (complementation group $\mathrm{E}$ ) with a significantly increased risk of development of skin cancer including melanoma [115]. Furthermore, DDB2-defective cells display reduced expression of p53 and concomitant attenuation of p53-dependent apoptosis and signaling in response to UV-induced DNA damage [116]. These results, thus, indicate that genes involved in cell cycle control and/or DNA damage response (for example, after UV irradiation) might be important markers for melanoma progression.

In a recent publication, Yang et al. [117] pointed out that UV-induced molecular changes might be responsible for tumorigenesis of melanoma. The authors measured UV-mediated alterations in over 47,000 transcripts in human primary melanocyte cultures using Affymetrix Human Genome U133 Plus 2.0 microarrays.

From the 100 most statistically robust changes on transcript level, there were 84 genes that were suppressed $>2$-fold and 99 genes that were induced $>2$-fold by UV radiation (UVB radiation at a dose of $500 \mathrm{~J} / \mathrm{m}^{2}$ ) when analyzed $24 \mathrm{~h}$ after irradiation. Using a pathway analysis program, the authors could identify a group of p53 target genes which were consistently elevated by UV radiation in 6 independent melanocyte cell lines. This group in- cludes again the cell cycle regulator CDKN1A and the DNA repair enzyme DDB2 (see above) as well as the receptor tyrosine kinase EPHA2, growth factor GDF15, ferrodoxin reductase FDXR, p53-inducible protein TP53I3, transcription factor ATF3, the $\beta$-adrenergic receptor ADBR2 and the WNT pathway regulator DKK1 (dickkopf homolog 1). Interestingly, by using quantitative PCR, the authors could furthermore show that in melanoma cell lines 3 genes of this group - CDKN1A, DDB2 and $A D R B 2$ - exhibit a trend towards loss of expression in melanoma. This raises the possibility that early UV response genes like CDKN1A and DDB2 also play a role in tumorigenesis (progression) as has been shown by others (see above) [112] and underscores once more the important role of UV radiation in melanomagenesis.

In summary, there is already good evidence that at least the expression levels of cell cycle regulator gene CDKN1A and DNA repair gene DDB2 might be good candidates for new biomarkers of melanoma development which must be further tested for functionality in the future.

\section{Nonmelanocytic Skin Cancer}

Basal Cell Carcinoma

Three microarray analyses have been published until now. The first study involved a limited cDNA microarray representing only 1,718 genes [118]. A second recent study comprehensively evaluated already 54,675 gene transcripts in 20 BCC samples versus 5 normal skin samples [119]. A recent third investigation uses a $21-\mathrm{k} \mathrm{cDNA}$ microarray not only to compare gene expression in BCC versus normal tissue, but furthermore investigates the gene expression profile in different morphological presentations of BCCs (superficial, nodular and morpheiform BCCs) compared to normal skin epithelium [120]. Focusing on genes involved in established pathways of tumorigenesis [hedgehog, Wnt, transforming growth factor- $\beta$, apoptosis, calcium ion channel, mitogen-activated protein kinase (MAPK) and cell cycle pathways], the authors were able to identify 93 gene that were differentially expressed between all BCCs and normal skin, and were also involved in 1 or more of the established pathways. Seventeen genes were involved in the hedgehog pathway, 27 in Wnt-signaling pathway, 22 in transforming growth factor- $\beta$-signaling pathway, 22 in MAPK and 21 in cell cycling. Using a gene ontology (GO annotation), as given in the DAVID annotation system, it was furthermore possible to classify certain genes which were enriched in different subtypes of BCC. In superficial BCC, gene classes which were enriched show a significant as- 
sociation with 'external stimuli function' and possibly 'positive regulation of enzyme activity' according to the GO annotation. In nodular BCCs, gene enrichment was identified in the categories 'regulation of cell growth', 'cell growth' and 'chromosome segregation' among others. Two functional GO categories, 'ectoderm development' and 'response to DNA damage stimulus', were uniquely identified with statistically significant expression exclusively in morpheiform BCCs. Where genes were commonly expressed in all 3 BCC subtypes, they showed the greatest fold change in morpheiform BCCs. The authors suggest this as an indication for morpheiform BCCs to be more 'aggressive' compared with superficial and nodular BCCs [120].

Expression levels of genes involved in the hedgehog, Wnt signaling and MAPK pathway, which are known to be involved in the etiology of BCC might be useful as biomarkers in the future. The results presented above, however, show that differential expression of genes in certain stages of BCC is complex. Future research has to show whether the expression levels of certain few genes or perhaps an expression level network of many genes might serve as new biomarker.

\section{Squamous Cell Carcinoma}

Using gene expression profiling (array techniques) or PCR technique, a number of genes and pathways have been identified which have been up- and downregulated during tumor progression of SCCs. When expression profiles were screened with cDNA arrays in normal epidermal keratinocytes, preneoplastic lesions and SCC cells, it was shown that 10 genes were up- and 27 downregulated, when the genome of neoplastic cells was compared to normal cells. Fifty-one percent of the genes altered in neoplastic cells were already altered in preneoplastic cells. PCR experiments verified the cDNA analysis and furthermore indicate that gene alterations in preneoplastic cells are associated with disruption of extracellular matrix production and apoptosis, whereas later stages of neoplasia involve alterations in genes for DNA repair (including GADD45) or MAPK signaling [121]. Quantitative RT-PCR measurements of mRNA expression in biopsies of normal skin, AK and SCC in 14 selected genes identified 10 of them to be dysregulated in $A K$ and/or SCC. An upregulation was found for COX4I1, COX5B, COX7C and NDRG1, CRLF3, and LMNA, while CNN2, CTSC (involved in respiration, communication, adhesion and metabolism), RPL15 and LGTN (involved in proliferation and adhesion) were downregulated [122]. In a study using the Affymetrix HG-U133A microarray tech- nology (containing 22,283 genes), Nindl et al. [123] added further information to their previous results [122]. Expression profiling in biopsy material from normal skin, AK and SCC showed that, overall, 42 genes were up- and 76 downregulated in skin cancer. Interestingly, the majority of differentially expressed genes were not described earlier in a context of (skin) cancer progression. Thirteen genes, which were up- or downregulated, were furthermore verified by quantitative RT-PCR. Upregulation was shown for CDH1, MAP4K4, IL-1RN, IL-4R, NM1, GRN, $R A B 31, T N C$ and $M M P 1$. Downregulation was found for ERCC1, APR-3, CG1-39 and NKEFB.

Dazard et al. [124] added further evidence that UV radiation is the important environmental risk factor for the induction and progression of skin cancer. It was shown (gene expression profiling, approx. 12,000 genes; Affimetrix) that upon UVB irradiation at a dose of $400 \mathrm{~J} / \mathrm{m}^{2}$ (similar to the estimated UVB dose received in a sunburn) 251 genes were up- and 322 downregulated in normal human keratinocytes. In SCCs, the corresponding numbers are 127 and 117. Whereas the response of keratinocytes to UVB involved regulation of key checkpoint genes ( $p 53, M D M 2$, p21Cip1, $\Delta N p 63$ ), no or little regulation was observed in SCCs. Interestingly, the authors conclude that tumorigenesis of SCC is, among other reasons, dependent on epigenetic effects, at least for certain genes involved in SCC development.

Expression profiling in SCC uncovers a complex picture. Beside expected candidates like GADD45 and genes in MAPK signaling, a large number of yet unexpected genes are differentially expressed if SCCs are compared with normal skin. It has to be tested in future research if any of these expression changes or a combination of them might be useful as a functional new biomarker.

All in all, the recent data from expression profiling and other high-throughput technologies, which could not be touched upon in this review, show that we get more and more information about important cellular pathways, genes and proteins that can be used as biomarkers in etiology, diagnostics, progression and prognostics of different forms of skin cancer. However, it also turned out that no single method/assay might be powerful enough (at the moment) to define the best marker(s) which should be used and it remains unclear if such a best marker actually exists. Therefore, different and (even more important) combined approaches should be used to characterize new biomarker combinations. In this context, a field that has been neglected and underestimated in the last decades is the field of epigenetics and its essential role in gene expression regulation. 


\section{Epigenetic Markers for Molecular Epidemiology of Skin Cancer}

The term epigenetics was first proposed in 1942 by Conrad Waddington. In this context, epigenetics described the process by which genotype is interpreted to yield a resulting phenotype [125]. More recently, epigenetics has been more commonly attributed to changes in gene expression without altering the gene sequence, such as chromatin organization and modification, including methylation [126].

Epigenetic regulation plays a key role in developmental steps during embryogenesis and in the control of stem cell fate [127-130]. Stochastic and environment-induced epigenetic modifications are known to be important steps in disease development (for example in mental and autoimmune disorders), cancer and aging [131, 132]. Recently, it could be shown that epigenetic gene alterations, like promoter $\mathrm{CpG}$ island hypermethylation, as well as certain histone tail modifications (acetylation, methylation) play an important role for gene expression related to tumorigenesis $[133,134]$. Promotor CpG island hypermethylation in combination with global DNA hypomethylation has already been termed a hallmark of cancer because this epigenetic pattern has been found in many tumor cell lines compared to normal tissue cells [135]. The pattern of epigenetic histone modifications dictates a 'histone code' which is 'read' by the gene regulatory machinery and allows the cell to either facilitate or inhibit the transcription of target genes [126].

CpG island hypermethylation and global hypomethylation in concert with the methylation of certain histone tails can lead to aberrant silencing of genes important to the initiation and progression of tumors $[136,137]$. There is evidence that in cancer cells many classic tumor suppressor genes, developmental transcription factors as well as genes responsible for DNA repair and cell cycle control are simultaneously epigenetically silenced [138], and that the loss of function of genes in tumors may have far more epigenetic causes than genetic ones [139]. This, and other findings, support the view that identifying new epigenetic markers will help to better understand skin cancer development and to characterize certain stages in tumor and (cancer) stem cell fate [36, 140-142], which might be useful in early detection of skin cancer.

Aberrant DNA methylation is now thought to be one of the most common molecular alterations in many cancer cell types [143]. Molecular genetic studies show that, for example, the p16INK4a gene is frequently inactivated by $5^{\prime}$-CpG hypermethylation in primary central nervous system lymphoma [144] and also in cutaneous SCC [145]. Furthermore, the human p14ARF promoter is aberrantly methylated in esophageal carcinomas [146], colorectal adenomas and carcinomas [147], in gliomas [144] and also in cutaneous SCC [145]. Using methylation-specific RTPCR, it was furthermore shown that in addition to p14 and $\mathrm{p} 16$ promotor hypermethylation also the $\mathrm{CpG}$ islands in promoters of the genes for retinoblastoma protein 1 and of E-cadherin (CDH1), the latter being linked to tumor invasiveness and distant metastasis, are inactivated by hypermethylation in the DNA of SCCs [148]. E-cadherin promoter hypermethylation seems to be correlated with more advanced stages of SCCs. Eighty-five percent of invasive SSCs, but only $50 \%$ of SCCs [148] and $44 \%$ of actinic keratosis, compared to only $22 \%$ in nonneoplastic skin, have been shown to be promoter hypermethylated at the $C D H 1$ locus in a study which, however, only examined a total of 33 cases (all stages of SCC together) [149]. Another recent study reports that $\mathrm{CDH} 1$ methylation in SCCs and BCCs was completely dependent on regions where the lesions had been taken from. Only lesions from sun-exposed parts of the human body showed $\mathrm{CDH} 1$ methylation. In BCC, the increase in methylation of the E-cadherin promoter was 390 -fold [150].

In MM, up to 50 genes have been shown to be silenced by promoter hypermethylation [126]. An important member in this group is the cyclin-dependent kinase inhibitor 2A gene (CDKN2A) coding for p16INK4a and p14ARF tumor suppressors. It controls the $\mathrm{G}_{1}-\mathrm{S}$ cell cycle checkpoint and can be repressed via chromosomal deletions of the 9p21 region, inactivation mutations and promoter hypermethylation [151-153]. van der Velden et al. [153] showed that p16INK4a was silenced in $32 \%$ of primary uveal melanoma and $50 \%$ of uveal melanoma cell lines. In primary cutaneous melanoma, a loss of p16 protein expression by hypermethylation of CDKN2A was found in 19\% and in 33\% of metastasis derived from melanoma [152]. Another tumor suppressor gene, methyltioadenosin phosphorylase (MTAP), is also repressed due to hypermethylation in melanoma [154] and MTAP protein is inversely correlated with tumor progression. Protein levels decreased from benign melanocytic nevi to metastatic melanoma in vivo [154]. A further tumor suppressor, whose expression is negatively correlated with progression of MM, is apoptotic protease activating factor-1 (Apaf-1), a cell death effector that mediates p53-dependent apoptosis [155]. Apaf-1 is silenced in melanoma by $\mathrm{LOH}$ and promoter hypermethylation, which leads to defects in apoptotic cell death [156]. Among the currently known approximately 50 genes which are hypermethyl- 
Table 2. Genes involved in epigenetic events which were found to be dysregulated in melanoma (for references, see Rothhammer et al. [126])

\begin{tabular}{llll}
\hline Gene function & Gene & Alteration & Reference \\
\hline DNA methyltransferase & DNMT1 & downregulation & Loriot et al., 2006 \\
\hline Histone deacetylase & HDAC1 & upregulation & Bandyopadhyay et al., 2004 \\
& HDAC2 & upregulation & Bandyopadhyay et al., 2004 \\
& HDAC3 & upregulation & Wang et al., 2005 \\
\hline Histone kinase & Sirtuin1 & constitutive activation & Thomas, 2006 \\
\hline ATP-dependent chromatin remodeling & ERK2 & overexpression & Nawa et al., 2000
\end{tabular}

ated in melanoma, the CDH1 and CDH8 genes of celladhesion molecules E-cadherin and P-cadherin can be found, too [157-159].

Beside hypermethylation, the opposite process, DNA hypomethylation, can also contribute to tumorigenesis. Hypomethylation can activate silenced regions in the genome, thereby activating the expression of, for example, harmful viral genes, repeat elements or genes which would normally be irreversibly silenced during development. Aberrant hypomethylation has been shown to disturb imprinting patterns and is also associated with chromosomal instability $[126,160]$. In MM an aberrant expression of the melanoma antigen (MAGE) has been reported, which is associated with promoter hypomethylation [161].

Epigenetic alterations in genes responsible for development, promotion and progression of skin cancer are most probably introduced via dysregulation of other genes which are coding for enzymes catalyzing the epigenetic changes in DNA or histones.

Table 2 shows a number of important genes which play crucial roles in maintaining the correct epigenetic status to be dysregulated in melanoma [126]. DNMT1 is involved in the maintenance of established DNA methylation patterns. HDAC1 to HDAC3 belong to the family of histone deacetylases. They catalyze the deacetylation of specific lysine residues of histone proteins, which promotes the condensation of chromatin, associated with diminished accessibility and repression of gene transcription. Sirtuins comprise a family of NAD+ dependent HDACs and sirtuin 1 has been shown to be involved in apoptosis pathways in melanoma. ERK2 (extracellular signal-regulated kinase $2 /$ mitogen-activated protein kinase 1) phosphorylates histones and thereby either alters charge of the amino acid and/or facilitates binding of transcription or chromatin remodeling factors which lead to major changes in chromatin structure. In melanoma, a constitutive activation of the MEK/ERK pathway has been observed by an activating mutation of the BRAF gene. Metastasis-associated antigen 1 (MAT1) is part of an ATP-dependent chromatin remodeling complex and has been shown to be highly expressed in melanoma cell lines [126].

It becomes clear from the data that dysregulation of these important genes (which by themselves might be seen as biomarkers) will be responsible for epigenetic changes in other genes which might then be used as further biomarkers.

A couple of investigations report growing evidence that epigenetic changes in (cancer) cells might be seen as a response to DNA-damaging agents (like, for example, UV radiation). Already in 1985, Becker et al. [162] reported that UVB-induced CPDs inhibited the maintenance as well as de novo methylation of viral and phage DNA in vitro by a purified liver methyltransferase. Four years later, it could be shown that another epigenetic modification, acetylation of N-terminal histone tails, plays an important role in DNA repair. Histone 4 in nucleosomes from human fibroblasts was transiently acetylated after $\mathrm{UV}(\mathrm{C})$ irradiation and facilitated repair synthesis which provide evidence that enhanced DNA repair occurs within nucleosome cores of hyperacetylated chromatin [163]. This has been confirmed by recent findings in yeast. Using chromatin immunoprecipitation, it could be shown that Lys-9 and/or Lys-14 of histone H3 in nucleosomes of the repressed MFA2 promoter become hyperacetylated after $\mathrm{UV}(\mathrm{C})$ irradiation of yeast cells. The level of UV-induced histone acetylation then gradually diminishes as repair of UV-induced CPDs proceeds. Accompanying this, chromatin in the promoter becomes more accessible 
to restriction enzymes after UV irradiation and gradually returns to the pre-UV state [164]. It has very recently been shown that in yeast the Gcn 5 histone acetyltransferase is responsible for primarily $\mathrm{H} 3$ acetylation and that increased accessibility of restriction sites is mediated by the yeast chromatin remodeling enzyme Swi2 [165].

Global hypomethylation has been described in the UVB-irradiated SKH hairless mouse model. It was demonstrated that this was the result of a UV-induced downregulation of maintenance DNA methyltransferase DNMT1 in the mice [166]. On the other hand, hypermethylation of specific genes involved in DNA repair abolishes their response to environmental stresses, like UV radiation. As an example, the GADD45 (growth arrest and DNA damage) family of proteins and its corresponding genes (GADD45A to GADD45G) have been identified as rapidly induced by DNA-damaging agents, like methylemethan sulfonate, UV radiation, hydroxyurea and ionizing radiation, leading to inhibition of cell growth and induction of apoptosis [167, 168]. Interestingly, it has been shown recently that GADD $45 G$ could be induced by heat shock and UV irradiation in human cell lines with unmethylated $\mathrm{CpG}$ island promoter of GADD45G, but not in those cell lines of primary tumors, which were characterized by $G A D D 45 G$ promoter $C p G$ island hypermethylation [169].

Interestingly enough, it has been demonstrated in mouse $\mathrm{C} 2 \mathrm{C} 12$ myoblasts and human HeLa cells that the maintenance methyltransferase, DNMT1, is recruited to sites of DNA repair after UVA laser-microirradiation of cells, thus pointing to a direct role of DNA methylation in the restoration of epigenetic information during DNA repair [170], which is known to be an essential cellular process in the etiology of (skin) cancer [171-173].

Furthermore, it has been pointed out in a very recent publication that a convergence of mutations and epigenetic alterations identifies genes in cancer that are fundamentally important for cancer initiation and progression, and predictive for clinical prognosis [174]. This combination of mutational alterations and expression profiling on a genetic and epigenetic basis will surely increase our knowledge about etiology, as well as diagnostic, prognostic and metastatic markers in skin cancer.

In conclusion, these findings strongly support the more and more emerging picture that $\mathrm{CpG}$ island hypermethylation in combination with global DNA hypomethylation must be seen as hallmarks of cancer [135], and that these epigenetic alterations could be induced by UV radiation, the main risk factor for skin cancer.

\section{Conclusion}

Skin cancer is the most frequent cancer worldwide and represents a fundamental health problem for the public. However, the main risk factor for skin cancer initiation, UV radiation, is known and skin cancer can be cured to nearly $100 \%$ if diagnosed in an early stage. These facts render skin cancer most sensitive to programs of primary and secondary prevention (early detection). Early detection can be facilitated by the use of new biomarkers which can be identified by means of modern molecular genetic methods (such as gene expression array techniques). Recent findings show that the use of these methods identifies biomarkers on the gene, protein, chromatin and cell level as well as in signaling pathways, which have not been thought, until recently, to be involved in progression and metastasis of skin tumors or to be used as prognostic markers. Sensitive biomarkers, which characterize the molecular response to UV radiation, the main risk factor for skin cancer, will help to better understand the genetic and epigenetic regulation and/or dysregulation which will lead to skin cancer.

Because of the huge amount of new information which has been collected in the last years, the emerging picture is still complex, but common features, like the promoter hypermethylation of E-cadherin (CDH1) in BCC, SCC and $\mathrm{MM}$ appear and might indicate that certain changes can be used as biomarkers for all types of skin cancer. Nevertheless, any putative new biomarker has to be tested for its functionality under practical conditions in the clinics or in skin cancer prevention.

New biomarkers will, furthermore, help to clarify the role of (cancer) stem cells in the development and therapy strategies of skin cancer. Importantly, new epigenetic biomarkers alone or in addition to genetic markers will increase the possibilities to characterize stem cell fate and to identify different stages in skin cancer development. They have the big potential to improve early detection of skin cancer.

References

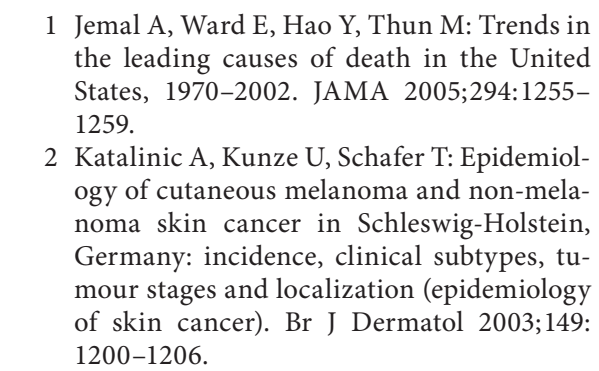

Greinert 
>3 Diepgen TL, Mahler V: The epidemiology of skin cancer. Br J Dermatol 2002;146(suppl 61):1-6.

4 Jemal A, Siegel R, Ward E, Murray T, Xu J, Smigal C, Thun MJ: Cancer statistics, 2006. CA Cancer J Clin 2006;56:106-130.

$\checkmark 5$ Balch CM, Buzaid AC, Soong SJ, Atkins MB, Cascinelli N, Coit DG, Fleming ID, Gershenwald JE, Houghton A Jr, Kirkwood JM, McMasters KM, Mihm MF, Morton DL, Reintgen DS, Ross MI, Sober A, Thompson JA, Thompson JF: Final version of the American Joint Committee on Cancer staging system for cutaneous melanoma. J Clin Oncol 2001; 19:3635-3648.

6 Boyle P, Dore JF, Autier P, Ringborg U: Cancer of the skin: a forgotten problem in Europe. Ann Oncol 2004;15:5-6.

$\checkmark 7$ de Vries E, Bray FI, Coebergh JW, Parkin DM: Changing epidemiology of malignant cutaneous melanoma in Europe 1953-1997: rising trends in incidence and mortality but recent stabilizations in western Europe and decreases in Scandinavia. Int J Cancer 2003; 107:119-126.

-8 de Vries E, Coebergh JW: Cutaneous malignant melanoma in Europe. Eur J Cancer 2004;40:2355-2366.

9 Pesch B, Ranft U, Jakubis P, Nieuwenhuijsen MJ, Hergemoller A, Unfried K, Jakubis M, Miskovic P, Keegan T: Environmental arsenic exposure from a coal-burning power plant as a potential risk factor for nonmelanoma skin carcinoma: results from a casecontrol study in the district of Prievidza, Slovakia. Am J Epidemiol 2002;155:798-809.

10 Nindl I, Gottschling M, Stockfleth E: Human papillomaviruses and non-melanoma skin cancer: basic virology and clinical manifestations. Dis Markers 2007;23:247-259.

-11 Armstrong BK, Kricker A: The epidemiology of UV induced skin cancer. J Photochem Photobiol B 2001;63:8-18.

$\checkmark 12$ Cleaver JE, Crowley E: UV damage, DNA repair and skin carcinogenesis. Front Biosci 2002;7:d1024-d1043.

$\checkmark 13$ de Gruijl FR, van Kranen HJ, Mullenders LH: UV-induced DNA damage, repair, mutations and oncogenic pathways in skin cancer. J Photochem Photobiol B 2001;63:1927.

- 14 Madan V, Hoban P, Strange RC, Fryer AA, Lear JT: Genetics and risk factors for basal cell carcinoma. Br J Dermatol 2006;154 (suppl 1):5-7.

15 Ramos J, Villa J, Ruiz A, Armstrong R, Matta J: UV dose determines key characteristics of nonmelanoma skin cancer. Cancer Epidemiol Biomarkers Prev 2004;13:2006-2011.

-16 Norval M, Cullen AP, de Gruijl FR, Longstreth J, Takizawa Y, Lucas RM, Noonan FP, van der Leun JC: The effects on human health from stratospheric ozone depletion and its interactions with climate change. Photochem Photobiol Sci 2007;6:232-251.
17 Abdel-Malek ZA, Knittel J, Kadekaro AL, Swope VB, Starner R: The melanocortin 1 receptor and the UV response of human melanocytes - a shift in paradigm. Photochem Photobiol 2008;84:501-508.

18 Dulon M, Weichenthal M, Blettner M, Breitbart M, Hetzer M, Greinert R, BaumgardtElms C, Breitbart EW: Sun exposure and number of nevi in 5- to 6-year-old European children. J Clin Epidemiol 2002;55:10751081.

19 Leiter U, Garbe C: Epidemiology of melanoma and nonmelanoma skin cancer - the role of sunlight. Adv Exp Med Biol 2008;624:89103.

20 Harrison SL, MacLennan R, Buettner PG: Sun exposure and the incidence of melanocytic nevi in young Australian children. Cancer Epidemiol Biomarkers Prev 2008; 17 : 2318-2324.

21 Besaratinia A, Pfeifer GP: Sunlight ultraviolet irradiation and BRAF V600 mutagenesis in human melanoma. Hum Mutat 2008;29: 983-991.

22 Thomas NE, Edmiston SN, Alexander A, Millikan RC, Groben PA, Hao H, Tolbert D, Berwick M, Busam K, Begg CB, Mattingly D, Ollila DW, Tse CK, Hummer A, Lee-Taylor J, Conway K: Number of nevi and early-life ambient UV exposure are associated with BRAF-mutant melanoma. Cancer Epidemiol Biomarkers Prev 2007;16:991-997.

23 Daya-Grosjean L, Couve-Privat S: Sonic hedgehog signaling in basal cell carcinomas. Cancer Lett 2005;225:181-192.

24 Xie J: Molecular biology of basal and squamous cell carcinomas. Adv Exp Med Biol 2008;624:241-251.

25 Lupi O: Correlations between the Sonic Hedgehog pathway and basal cell carcinoma. Int J Dermatol 2007;46:1113-1117.

$\checkmark 26$ Benjamin CL, Melnikova VO, Ananthaswamy HN: P53 protein and pathogenesis of melanoma and nonmelanoma skin cancer. Adv Exp Med Biol 2008;624:265-282.

-27 Perez-Ordonez B, Beauchemin M, Jordan RC: Molecular biology of squamous cell carcinoma of the head and neck. J Clin Pathol 2006;59:445-453.

28 Hussein MR: Ultraviolet radiation and skin cancer: molecular mechanisms. J Cutan Pathol 2005;32:191-205.

29 Bosserhoff AK: Novel biomarkers in malignant melanoma. Clin Chim Acta 2006;367: 28-35.

30 Sekulic A, Haluska PJr, Miller AJ, Genebriera DL, Ejadi S, Pulido JS, Salomao DR, Thorland EC, Vile RG, Swanson DL, Pockaj BA, Laman SD, Pittelkow MR, Markovic SN: Malignant melanoma in the 21st century: the emerging molecular landscape. Mayo Clin Proc 2008;83:825-846.

31 Dahl C, Guldberg P: The genome and epigenome of malignant melanoma. APMIS 2007;115:1161-1176
32 Gerdes MJ, Yuspa SH: The contribution of epidermal stem cells to skin cancer. Stem Cell Rev 2005;1:225-231.

33 Yan X, Owens DM: The skin: a home to multiple classes of epithelial progenitor cells. Stem Cell Rev 2008;4:113-118.

34 Faurschou A, Haedersdal M, Poulsen T, Wulf HC: Squamous cell carcinoma induced by ultraviolet radiation originates from cells of the hair follicle in mice. Exp Dermatol 2007; 16:485-489.

35 Grichnik JM: Melanoma, nevogenesis, and stem cell biology. J Invest Dermatol 2008; 128:2365-2380

>36 Zabierowski SE, Herlyn M: Melanoma stem cells: the dark seed of melanoma. J Clin Oncol 2008;26:2890-2894.

37 Schwabe M, Lubbert M: Epigenetic lesions in malignant melanoma. Curr Pharm Biotechnol 2007;8:382-387.

38 Breitbart EW, Greinert R, Volkmer B: Effectiveness of information campaigns. Prog Biophys Mol Biol 2006;92:167-172.

>39 Greinert R, Breitbart EW, Mohar P, Volkmer $\mathrm{B}$ : Health initiatives for the prevention of skin cancer. Adv Exp Med Biol 2008;624: 125-136.

40 Gandini S, Sera F, Cattaruzza MS, Pasquini P, Abeni D, Boyle P, Melchi CF: Meta-analysis of risk factors for cutaneous melanoma: I. Common and atypical naevi. Eur J Cancer 2005;41:28-44.

41 Gandini S, Sera F, Cattaruzza MS, Pasquini P, Picconi O, Boyle P, Melchi CF: Meta-analysis of risk factors for cutaneous melanoma: II. Sun exposure. Eur J Cancer 2005;41:4560.

-42 Gandini S, Sera F, Cattaruzza MS, Pasquini P, Zanetti R, Masini C, Boyle P, Melchi CF: Meta-analysis of risk factors for cutaneous melanoma: III. Family history, actinic damage and phenotypic factors. Eur J Cancer 2005;41:2040-2059.

$\checkmark 43$ Chen YC, Hunter DJ: Molecular epidemiology of cancer. CA Cancer J Clin 2005;55:4554.

44 Garbe C, Buttner P, Weiss J, Soyer HP, Stocker U, Kruger S, Roser M, Weckbecker J, Panizzon R, Bahmer F: Associated factors in the prevalence of more than 50 common melanocytic nevi, atypical melanocytic nevi, and actinic lentigines: multicenter case-control study of the Central Malignant Melanoma Registry of the German Dermatological Society. J Invest Dermatol 1994;102:700705.

45 Garbe C, Buttner P, Weiss J, Soyer HP, Stocker U, Kruger S, Roser M, Weckbecker J, Panizzon R, Bahmer F: Risk factors for developing cutaneous melanoma and criteria for identifying persons at risk: multicenter casecontrol study of the Central Malignant Melanoma Registry of the German Dermatological Society. J Invest Dermatol 1994;102: 695-699. 
46 Gallagher RP, McLean DI, Yang CP, Coldman AJ, Silver HK, Spinelli JJ, Beagrie M: Suntan, sunburn, and pigmentation factors and the frequency of acquired melanocytic nevi in children. Similarities to melanoma: the Vancouver Mole Study. Arch Dermatol 1990;126:770-776.

-47 Harrison SL, MacLennan R, Speare R, Wronski I: Sun exposure and melanocytic naevi in young Australian children. Lancet 1994;344: 1529-1532.

-48 Kelly JW, Rivers JK, MacLennan R, Harrison S, Lewis AE, Tate BJ: Sunlight: a major factor associated with the development of melanocytic nevi in Australian schoolchildren. J Am Acad Dermatol 1994;30:40-48.

-49 Richard MA, Grob JJ, Gouvernet J, Culat J, Normand P, Zarour H, Bonerandi JJ: Role of sun exposure on nevus. First study in age-sex phenotype-controlled populations. Arch Dermatol 1993;129:1280-1285.

-50 Sorahan T, Ball PM, Grimley RP, Pope D: Benign pigmented nevi in children from Kidderminster, England: prevalence and associated factors. J Am Acad Dermatol 1990;22: 747-750.

-51 Wiecker TS, Luther H, Buettner P, Bauer J, Garbe C: Moderate sun exposure and nevus counts in parents are associated with development of melanocytic nevi in childhood: a risk factor study in 1,812 kindergarten children. Cancer 2003;97:628-638.

-52 Rosenstein BS, Mitchell DL: Action spectra for the induction of pyrimidine(6-4)pyrimidone photoproducts and cyclobutane pyrimidine dimers in normal human skin fibroblasts. Photochem Photobiol 1987;45: 775-780.

53 Mitchell DL, Brash DE, Nairn RS: Rapid repair kinetics of pyrimidine(6-4)pyrimidone photoproducts in human cells are due to excision rather than conformational change. Nucleic Acids Res 1990;18:963-971.

54 Greinert R, Boguhn O, Harder D, Breitbart EW, Mitchell DL, Volkmer B: The dose dependence of cyclobutane dimer induction and repair in UVB-irradiated human keratinocytes. Photochem Photobiol 2000;72:701708.

55 Wang LE, Li C, Strom SS, Goldberg LH, Brewster A, Guo Z, Qiao Y, Clayman GL, Lee JJ, El Naggar AK, Prieto VG, Duvic M, Lippman SM, Weber RS, Kripke ML, Wei Q: Repair capacity for UV light induced DNA damage associated with risk of nonmelanoma skin cancer and tumor progression. Clin Cancer Res 2007;13:6532-6539.

56 Wei Q, Lee JE, Gershenwald JE, Ross MI, Mansfield PF, Strom SS, Wang LE, Guo Z, Qiao Y, Amos CI, Spitz MR, Duvic M: Repair of UV light-induced DNA damage and risk of cutaneous malignant melanoma. J Natl Cancer Inst 2003;95:308-315.
57 Wang LE, Xiong P, Strom SS, Goldberg LH, Lee JE, Ross MI, Mansfield PF, Gershenwald JE, Prieto VG, Cormier JN, Duvic M, Clayman GL, Weber RS, Lippman SM, Amos CI, Spitz MR, Wei Q: In vitro sensitivity to ultraviolet $\mathrm{B}$ light and skin cancer risk: a casecontrol analysis. J Natl Cancer Inst 2005;97: 1822-1831.

58 Sage E, Lamolet B, Brulay E, Moustacchi E, Chateauneuf A, Drobetsky EA: Mutagenic specificity of solar UV light in nucleotide excision repair-deficient rodent cells. Proc Natl Acad Sci USA 1996;93:176-180.

59 Dumaz N, Drougard C, Sarasin A, DayaGrosjean L: Specific UV-induced mutation spectrum in the p53 gene of skin tumors from DNA-repair-deficient xeroderma pigmentosum patients. Proc Natl Acad Sci USA 1993;90:10529-10533.

60 Nakazawa H, English D, Randell PL, Nakazawa K, Martel N, Armstrong BK, Yamasaki $\mathrm{H}$ : UV and skin cancer: specific p53 gene mutation in normal skin as a biologically relevant exposure measurement. Proc Natl Acad Sci USA 1994;91:360-364.

-61 Ravanat JL, Douki T, Cadet J: Direct and indirect effects of UV radiation on DNA and its components. J Photochem Photobiol B 2001;63:88-102.

62 Besaratinia A, Kim SI, Pfeifer GP: Rapid repair of UVA-induced oxidized purines and persistence of UVB-induced dipyrimidine lesions determine the mutagenicity of sunlight in mouse cells. FASEB J 2008;22:23792392.

63 Runger TM, Kappes UP: Mechanisms of mutation formation with long-wave ultraviolet light (UVA). Photodermatol Photoimmunol Photomed 2008;24:2-10.

64 Ikehata H, Kudo H, Masuda T, Ono T: UVA induces $\mathrm{C}->\mathrm{T}$ transitions at methyl-CpGassociated dipyrimidine sites in mouse skin epidermis more frequently than UVB. Mutagenesis 2003;18:511-519.

65 Matsumura Y, Ananthaswamy HN: Molecular mechanisms of photocarcinogenesis. Front Biosci 2002;7:d765-d783.

66 Hussain SP, Hollstein MH, Harris CC: p53 tumor suppressor gene: at the crossroads of molecular carcinogenesis, molecular epidemiology, and human risk assessment. Ann NY Acad Sci 2000;919:79-85.

67 Ziegler A, Leffell DJ, Kunala S, Sharma HW, Gailani M, Simon JA, Halperin AJ, Baden HP, Shapiro PE, Bale AE: Mutation hotspots due to sunlight in the p53 gene of nonmelanoma skin cancers. Proc Natl Acad Sci USA 1993;90:4216-4220.

68 Brash DE, Ziegler A, Jonason AS, Simon JA, Kunala S, Leffell DJ: Sunlight and sunburn in human skin cancer: p53, apoptosis, and tumor promotion. J Investig Dermatol Symp Proc 1996;1:136-142.

69 Brash DE: Roles of the transcription factor p53 in keratinocyte carcinomas. Br J Dermatol 2006;154(suppl 1):8-10.
70 van der Riet P, Karp D, Farmer E, Wei Q, Grossman L, Tokino K, Ruppert JM, Sidransky D: Progression of basal cell carcinoma through loss of chromosome $9 \mathrm{q}$ and inactivation of a single p53 allele. Cancer Res 1994; 54:25-27.

71 Nelson MA, Einspahr JG, Alberts DS, Balfour CA, Wymer JA, Welch KL, Salasche SJ, Bangert JL, Grogan TM, Bozzo PO: Analysis of the p53 gene in human precancerous actinic keratosis lesions and squamous cell cancers. Cancer Lett 1994;85:23-29.

72 Brash DE: Sunlight and the onset of skin cancer. Trends Genet 1997;13:410-414.

73 Fusenig NE, Boukamp P: Multiple stages and genetic alterations in immortalization, malignant transformation, and tumor progression of human skin keratinocytes. Mol Carcinog 1998;23:144-158.

74 Mitchell DL, Greinert R, de Gruijl FR, Guikers KL, Breitbart EW, Byrom M, Gallmeier MM, Lowery MG, Volkmer B: Effects of chronic low-dose ultraviolet $\mathrm{B}$ radiation on DNA damage and repair in mouse skin. Cancer Res 1999;59:2875-2884.

75 Mitchell DL, Volkmer B, Breitbart EW, Byrom M, Lowery MG, Greinert R: Identification of a non-dividing subpopulation of mouse and human epidermal cells exhibiting high levels of persistent ultraviolet photodamage. J Invest Dermatol 2001;117:590595.

76 Morris RJ: Keratinocyte stem cells: targets for cutaneous carcinogens. J Clin Invest 2000;106:3-8.

77 Braun KM, Watt FM: Epidermal label-retaining cells: background and recent applications. J Investig Dermatol Symp Proc 2004; 9:196-201.

78 Watt FM: Epidermal stem cells: markers, patterning and the control of stem cell fate. Philos Trans R Soc Lond B Biol Sci 1998;353: 831-837.

79 Giangreco A, Qin M, Pintar JE, Watt FM: Epidermal stem cells are retained in vivo throughout skin aging. Aging Cell 2008;7: 250-259.

80 Nijhof JG, van Pelt C, Mulder AA, Mitchell DL, Mullenders LH, de Gruijl FR: Epidermal stem and progenitor cells in murine epidermis accumulate UV damage despite NER proficiency. Carcinogenesis 2007;28:792800 .

81 Quinn AG, Sikkink S, Rees JL: Basal cell carcinomas and squamous cell carcinomas of human skin show distinct patterns of chromosome loss. Cancer Res 1994;54:47564759.

82 Danaee H, Karagas MR, Kelsey KT, Perry AE, Nelson HH: Allelic loss at Drosophila patched gene is highly prevalent in basal and squamous cell carcinomas of the skin. J Invest Dermatol 2006;126:1152-1158. 
$>83$ Healy E, Belgaid CE, Takata M, Vahlquist A, Rehman I, Rigby H, Rees JL: Allelotypes of primary cutaneous melanoma and benign melanocytic nevi. Cancer Res 1996;56:589593.

84 Park WS, Vortmeyer AO, Pack S, Duray PH, Boni R, Guerami AA, Emmert-Buck MR, Liotta LA, Zhuang Z: Allelic deletion at chromosome 9p21(p16) and 17p13(p53) in microdissected sporadic dysplastic nevus. Hum Pathol 1998;29:127-130.

-85 Kraemer KH, Patronas NJ, Schiffmann R, Brooks BP, Tamura D, Digiovanna JJ: Xeroderma pigmentosum, trichothiodystrophy and Cockayne syndrome: a complex genotype-phenotype relationship. Neuroscience 2007; 145:1388-1396.

-86 Hahn H, Wicking C, Zaphiropoulous PG, Gailani MR, Shanley S, Chidambaram A, Vorechovsky I, Holmberg E, Unden AB, Gillies S, Negus K, Smyth I, Pressman C, Leffell DJ, Gerrard B, Goldstein AM, Dean M, Toftgard R, Chenevix-Trench G, Wainwright B, Bale AE: Mutations of the human homolog of Drosophila patched in the nevoid basal cell carcinoma syndrome. Cell 1996;85:841851.

-87 Gailani MR, Stahle-Backdahl M, Leffell DJ, Glynn M, Zaphiropoulos PG, Pressman C, Unden $\mathrm{AB}$, Dean M, Brash DE, Bale AE, Toftgard R: The role of the human homologue of Drosophila patched in sporadic basal cell carcinomas. Nat Genet 1996;14:7881.

-88 Oro AE, Higgins KM, Hu Z, Bonifas JM, Epstein EH Jr, Scott MP: Basal cell carcinomas in mice overexpressing sonic hedgehog. Science 1997;276:817-821.

-89 Kefford RF, Newton Bishop JA, Bergman W, Tucker MA: Counseling and DNA testing for individuals perceived to be genetically predisposed to melanoma: a consensus statement of the Melanoma Genetics Consortium. J Clin Oncol 1999;17:3245-3251.

$\checkmark 90$ Chin L, Pomerantz J, DePinho RA: The INK4a/ARF tumor suppressor: one genetwo products - two pathways. Trends Biochem Sci 1998;23:291-296.

$\checkmark 91$ Sharpless E, Chin L: The INK4a/ARF locus and melanoma. Oncogene 2003;22:30923098.

-92 Utikal J, Schadendorf D, Ugurel S: Serologic and immunohistochemical prognostic biomarkers of cutaneous malignancies. Arch Dermatol Res 2007;298:469-477.

-93 Bosserhoff AK, Hein R, Bogdahn U, Buettner $\mathrm{R}$ : Structure and promoter analysis of the gene encoding the human melanoma-inhibiting protein MIA. J Biol Chem 1996;271: 490-495

-94 Bosserhoff AK: Melanoma inhibitory activity (MIA): an important molecule in melanoma development and progression. Pigment Cell Res 2005;18:411-416.
-95 Poser I, Tatzel J, Kuphal S, Bosserhoff AK: Functional role of MIA in melanocytes and early development of melanoma. Oncogene 2004;23:6115-6124.

96 Vance KW, Goding CR: The transcription network regulating melanocyte development and melanoma. Pigment Cell Res 2004;17:318-325.

-97 Wang W, Edington HD, Rao UN, Jukic DM, Land SR, Ferrone S, Kirkwood JM: Modulation of signal transducers and activators of transcription 1 and 3 signaling in melanoma by high-dose IFN $\alpha 2 b$. Clin Cancer Res 2007;13:1523-1531.

-98 Wang W, Edington HD, Rao UN, Jukic DM, Wang H, Shipe-Spotloe JM, Kirkwood JM STAT3 as a biomarker of progression in atypical nevi of patients with melanoma: dose-response effects of systemic IFNo therapy. J Invest Dermatol 2008;128:19972002.

-99 Arumi-Uria M, McNutt NS, Finnerty B Grading of atypia in nevi: correlation with melanoma risk. Mod Pathol 2003;16:764771.

100 Shapiro M, Chren MM, Levy RM, Elder DE, LeBoit PE, Mihm MC Jr, Margolis DJ, Gimotty PA, Ming ME: Variability in nomenclature used for nevi with architectura disorder and cytologic atypia (microscopically dysplastic nevi) by dermatologists and dermatopathologists. J Cutan Pathol 2004, 31:523-530.

101 Elder DE: Precursors to melanoma and their mimics: nevi of special sites. Mod Pathol 2006;19(suppl 2):S4-S20.

102 Nambiar S, Mirmohammadsadegh A, Doroudi R, Gustrau A, Marini A, Roeder G, Ruzicka T, Hengge UR: Signaling networks in cutaneous melanoma metastasis identified by complementary DNA microarrays. Arch Dermatol 2005;141:165-173.

103 de Wit NJ, Rijntjes J, Diepstra JH, van Kup pevelt TH, Weidle UH, Ruiter DJ, van Muijen GN: Analysis of differential gene expression in human melanocytic tumour lesions by custom made oligonucleotide arrays. Br J Cancer 2005;92:2249-2261.

104 Dooley TP, Curto EV, Davis RL, Grammatico P, Robinson ES, Wilborn TW: DNA microarrays and likelihood ratio bioinformatic methods: discovery of human melanocyte biomarkers. Pigment Cell Res 2003; 16:245-253.

105 Mirmohammadsadegh A, Baer A, Nambiar S, Bardenheuer W, Hengge UR: Rapid identification of dysregulated genes in cutaneous malignant melanoma metastases using cDNA technology. Cells Tissues Organs 2004;177:119-123.

106 Seykora JT, Jih D, Elenitsas R, Horng WH, Elder DE: Gene expression profiling of melanocytic lesions. Am J Dermatopathol 2003;25:6-11.
107 Zuidervaart W, van der Velden PA, Hurks $\mathrm{MH}$, van Nieuwpoort FA, Out-Luiting CJ, Singh AD, Frants RR, Jager MJ, Gruis NA: Gene expression profiling identifies tumour markers potentially playing a role in uveal melanoma development. Br J Cancer 2003;89:1914-1919.

108 Hoek KS: DNA microarray analyses of melanoma gene expression: a decade in the mines. Pigment Cell Res 2007;20:466-484.

109 Haqq C, Nosrati M, Sudilovsky D, Crothers J, Khodabakhsh D, Pulliam BL, Federman S, Miller JR, III, Allen RE, Singer MI, Leong SP, Ljung BM, Sagebiel RW, Kashani-Sabet M: The gene expression signatures of melanoma progression. Proc Natl Acad Sci USA 2005; 102:6092-6097.

110 Hoek K, Rimm DL, Williams KR, Zhao H, Ariyan S, Lin A, Kluger HM, Berger AJ, Cheng E, Trombetta ES, Wu T, Niinobe M, Yoshikawa K, Hannigan GE, Halaban R: Expression profiling reveals novel pathways in the transformation of melanocytes to melanomas. Cancer Res 2004;64:52705282.

111 Talantov D, Mazumder A, Yu JX, Briggs T, Jiang Y, Backus J, Atkins D, Wang Y: Novel genes associated with malignant melanoma but not benign melanocytic lesions. Clin Cancer Res 2005;11:7234-7242.

112 Kaufmann WK, Nevis KR, Qu P, Ibrahim JG, Zhou T, Zhou Y, Simpson DA, HelmsDeaton J, Cordeiro-Stone M, Moore DT, Thomas NE, Hao H, Liu Z, Shields JM, Scott GA, Sharpless NE: Defective cell cycle checkpoint functions in melanoma are associated with altered patterns of gene expression. J Invest Dermatol 2008;128:175187.

113 Bartkova J, Horejsi Z, Koed K, Kramer A, Tort F, Zieger K, Guldberg P, Sehested M, Nesland JM, Lukas C, Orntoft T, Lukas J, Bartek J: DNA damage response as a candidate anti-cancer barrier in early human tumorigenesis. Nature 2005;434:864-870.

114 Warters RL, Adamson PJ, Pond CD, Leachman SA: Melanoma cells express elevated levels of phosphorylated histone H2AX foci. J Invest Dermatol 2005;124:807-817.

115 Itoh T, O’Shea C, Linn S: Impaired regulation of tumor suppressor p53 caused by mutations in the xeroderma pigmentosum DDB2 gene: mutual regulatory interactions between p48(DDB2) and p53. Mol Cell Biol 2003;23:7540-7553.

116 Itoh T, Cado D, Kamide R, Linn S: DDB2 gene disruption leads to skin tumors and resistance to apoptosis after exposure to ultraviolet light but not a chemical carcinogen. Proc Natl Acad Sci USA 2004;101: 2052-2057.

-117 Yang G, Zhang G, Pittelkow MR, Ramoni M, Tsao H: Expression profiling of UVB response in melanocytes identifies a set of p53-target genes. J Invest Dermatol 2006; 126:2490-2506 
-118 Howell BG, Solish N, Lu C, Watanabe H, Mamelak AJ, Freed I, Wang B, Sauder DN: Microarray profiles of human basal cell carcinoma: insights into tumor growth and behavior. J Dermatol Sci 2005;39:39-51.

-119 O’Driscoll L, McMorrow J, Doolan P, McKiernan E, Mehta JP, Ryan E, Gammell P, Joyce H, O’Donovan N, Walsh N, Clynes M: Investigation of the molecular profile of basal cell carcinoma using whole genome microarrays. Mol Cancer 2006;5:74.

-120 Yu M, Zloty D, Cowan B, Shapiro J, Haegert A, Bell RH, Warshawski L, Carr N, McElwee KJ: Superficial, nodular, and morpheiform basal-cell carcinomas exhibit distinct gene expression profiles. J Invest Dermatol 2008;128:1797-1805.

-121 Serewko MM, Popa C, Dahler AL, Smith L, Strutton GM, Coman W, Dicker AJ, Saunders NA: Alterations in gene expression and activity during squamous cell carcinoma development. Cancer Res 2002;62: 3759-3765.

- 122 Dang C, Gottschling M, Manning K, O'Currain E, Schneider S, Sterry W, Stockfleth E, Nindl I: Identification of dysregulated genes in cutaneous squamous cell carcinoma. Oncol Rep 2006;16:513-519.

-123 Nindl I, Dang C, Forschner T, Kuban RJ, Meyer T, Sterry W, Stockfleth E: Identification of differentially expressed genes in cutaneous squamous cell carcinoma by microarray expression profiling. Mol Cancer 2006;5:30.

-124 Dazard JE, Gal H, Amariglio N, Rechavi G, Domany E, Givol D: Genome-wide comparison of human keratinocyte and squamous cell carcinoma responses to UVB irradiation: implications for skin and epithelial cancer. Oncogene 2003;22:29933006.

125 Slack JM: Conrad Hal Waddington: the last Renaissance biologist? Nat Rev Genet 2002; 3:889-895.

126 Rothhammer T, Bosserhoff AK: Epigenetic events in malignant melanoma. Pigment Cell Res 2007;20:92-111.

127 Jones PA, Baylin SB: The epigenomics of cancer. Cell 2007;128:683-692.

- 128 Bernstein BE, Mikkelsen TS, Xie X, Kamal M, Huebert DJ, Cuff J, Fry B, Meissner A, Wernig M, Plath K, Jaenisch R, Wagschal A, Feil R, Schreiber SL, Lander ES: A bivalent chromatin structure marks key developmental genes in embryonic stem cells. Cell 2006;125:315-326.

-129 Bernstein BE, Meissner A, Lander ES: The mammalian epigenome. Cell 2007;128: 669-681.

-130 Surani MA, Hayashi K, Hajkova P: Genetic and epigenetic regulators of pluripotency. Cell 2007;128:747-762.

131 Jiang SW, Li J, Podratz K, Dowdy S: Application of DNA methylation biomarkers for endometrial cancer management. Expert Rev Mol Diagn 2008;8:607-616.
132 Fraga MF, Esteller M: Epigenetics and aging: the targets and the marks. Trends Genet 2007;23:413-418.

133 Esteller M: The necessity of a human epigenome project. Carcinogenesis 2006;27: 1121-1125.

134 Feinberg AP, Ohlsson R, Henikoff S: The epigenetic progenitor origin of human cancer. Nat Rev Genet 2006;7:21-33.

135 Laird PW: Cancer epigenetics. Hum Mol Genet 2005;14:R65-R76.

136 Ting AH, McGarvey KM, Baylin SB: The cancer epigenome - components and functional correlates. Genes Dev 2006;20:32153231.

137 Li B, Carey M, Workman JL: The role of chromatin during transcription. Cell 2007; 128:707-719.

138 Baylin SB, Ohm JE: Epigenetic gene silencing in cancer - a mechanism for early oncogenic pathway addiction? Nat Rev Cancer 2006;6:107-116.

139 Jones PA, Baylin SB: The fundamental role of epigenetic events in cancer. Nat Rev Genet 2002;3:415-428.

140 Prince ME, Sivanandan R, Kaczorowski A Wolf GT, Kaplan MJ, Dalerba P, Weissman IL, Clarke MF, Ailles LE: Identification of a subpopulation of cells with cancer stem cell properties in head and neck squamous cell carcinoma. Proc Natl Acad Sci USA 2007; 104:973-978

141 Bennett DC: How to make a melanoma: what do we know of the primary clonal events? Pigment Cell Melanoma Res 2008; 21:27-38.

142 Houben R, Wischhusen J, Menaa F, Synwoldt P, Schrama D, Brocker EB, Becker JC: Melanoma stem cells: targets for successful therapy? J Dtsch Dermatol Ges 2008;6:541546.

143 Esteller M: Aberrant DNA methylation as a cancer-inducing mechanism. Annu Rev Pharmacol Toxicol 2005;45:629-656.

144 Nakamura M, Watanabe T, Klangby U, Asker C, Wiman K, Yonekawa Y, Kleihues P, Ohgaki H: p14ARF deletion and methylation in genetic pathways to glioblastomas. Brain Pathol 2001;11:159-168.

145 Brown VL, Harwood CA, Crook T, Cronin JG, Kelsell DP, Proby CM: p16INK4a and p14ARF tumor suppressor genes are commonly inactivated in cutaneous squamous cell carcinoma. J Invest Dermatol 2004;122: 1284-1292.

146 Xing EP, Nie Y, Song Y, Yang GY, Cai YC Wang LD, Yang CS: Mechanisms of inactivation of p14ARF, p15INK4b, and p16INK4a genes in human esophageal squamous cell carcinoma. Clin Cancer Res 1999;5:27042713.

147 Esteller M, Tortola S, Toyota M, Capella G, Peinado MA, Baylin SB, Herman JG: Hypermethylation-associated inactivation of p14(ARF) is independent of p16(INK4a) methylation and p53 mutational status. Cancer Res 2000;60:129-133.
148 Murao K, Kubo Y, Ohtani N, Hara E, Arase S: Epigenetic abnormalities in cutaneous squamous cell carcinomas: frequent inactivation of the $\mathrm{RB} 1 / \mathrm{p} 16$ and $\mathrm{p} 53$ pathways. $\mathrm{Br}$ J Dermatol 2006;155:999-1005.

149 Chiles MC, Ai L, Zuo C, Fan CY, Smoller BR: E-cadherin promoter hypermethylation in preneoplastic and neoplastic skin lesions. Mod Pathol 2003;16:1014-1018.

150 Sathyanarayana UG, Moore AY, Li L, Padar A, Majmudar K, Stastny V, Makarla P, Suzuki M, Minna JD, Feng Z, Gazdar AF: Sun exposure related methylation in malignant and non-malignant skin lesions. Cancer Lett 2007;245:112-120.

151 Dobrowolski R, Hein R, Buettner R, Bosserhoff AK: Loss of p14ARF expression in melanoma. Arch Dermatol Res 2002;293:545551.

152 Straume O, Smeds J, Kumar R, Hemminki K, Akslen LA: Significant impact of promoter hypermethylation and the $540 \mathrm{C}>\mathrm{T}$ polymorphism of CDKN2A in cutaneous melanoma of the vertical growth phase. Am J Pathol 2002;161:229-237.

153 van der Velden PA, Metzelaar-Blok JA, Bergman W, Monique H, Hurks H, Frants RR, Gruis NA, Jager MJ: Promoter hypermethylation: a common cause of reduced p16(INK4a) expression in uveal melanoma. Cancer Res 2001;61:5303-5306.

154 Behrmann I, Wallner S, Komyod W, Heinrich PC, Schuierer M, Buettner R, Bosserhoff AK: Characterization of methylthioadenosinphosphorylase(MTAP)expression in malignant melanoma. Am J Pathol 2003; 163:683-690.

155 Niedojadlo K, Labedzka K, Lada E, Milewska A, Chwirot BW: Apaf-1 expression in human cutaneous melanoma progression and in pigmented nevi. Pigment Cell Res 2006; 19:43-50.

156 Soengas MS, Capodieci P, Polsky D, Mora J, Esteller M, Opitz-Araya X, McCombie R, Herman JG, Gerald WL, Lazebnik YA, Cordon-Cardo C, Lowe SW: Inactivation of the apoptosis effector Apaf-1 in malignant melanoma. Nature 2001;409:207-211.

-157 Paz MF, Fraga MF, Avila S, Guo M, Pollan M, Herman JG, Esteller M: A systematic profile of DNA methylation in human cancer cell lines. Cancer Res 2003;63:11141121.

158 Poser I, Dominguez D, de Herreros AG, Varnai A, Buettner R, Bosserhoff AK: Loss of E-cadherin expression in melanoma cells involves up-regulation of the transcriptional repressor Snail. J Biol Chem 2001; 276:24661-24666.

159 Tsutsumida A, Hamada J, Tada M, Aoyama T, Furuuchi K, Kawai Y, Yamamoto Y, Sugihara T, Moriuchi T: Epigenetic silencing of $\mathrm{E}$ - and $\mathrm{P}$-cadherin gene expression in human melanoma cell lines. Int J Oncol 2004; 25:1415-1421. 
160 Wilson AS, Power BE, Molloy PL: DNA hypomethylation and human diseases. Biochim Biophys Acta 2007;1775:138-162.

161 van Doorn R, Gruis NA, Willemze R, van der Velden PA, Tensen CP: Aberrant DNA methylation in cutaneous malignancies. Semin Oncol 2005;32:479-487.

162 Becker FF, Holton P, Ruchirawat M, Lapeyre JN: Perturbation of maintenance and de novo DNA methylation in vitro by UVB (280-340 nm)-induced pyrimidine photodimers. Proc Natl Acad Sci USA 1985;82: 6055-6059.

163 Ramanathan B, Smerdon MJ: Enhanced DNA repair synthesis in hyperacetylated nucleosomes. J Biol Chem 1989;264:1102611034.

164 Yu Y, Teng Y, Liu H, Reed SH, Waters R: UV irradiation stimulates histone acetylation and chromatin remodeling at a repressed yeast locus. Proc Natl Acad Sci USA 2005; 102:8650-8655.

165 Waters R, Reed SH, Yu Y, Teng Y: Chromatin modifications and nucleotide excision repair. SEB Exp Biol Ser 2008;59:189-201.
166 Mittal A, Piyathilake C, Hara Y, Katiyar SK: Exceptionally high protection of photocarcinogenesis by topical application of (-)-epigallocatechin-3-gallate in hydrophilic cream in SKH-1 hairless mouse model: relationship to inhibition of UVBinduced global DNA hypomethylation. Neoplasia 2003;5:555-565.

167 Fornace AJ Jr, Nebert DW, Hollander MC, Luethy JD, Papathanasiou M, Fargnoli J, Holbrook NJ: Mammalian genes coordinately regulated by growth arrest signals and DNA-damaging agents. Mol Cell Biol 1989;9:4196-4203.

168 Liebermann DA, Hoffman B: Gadd45 in stress signaling. J Mol Signal 2008;3:15.

169 Ying J, Srivastava G, Hsieh WS, Gao Z, Murray P, Liao SK, Ambinder R, Tao Q: The stress-responsive gene GADD45G is a functional tumor suppressor, with its response to environmental stresses frequently disrupted epigenetically in multiple tumors. Clin Cancer Res 2005;11:6442-6449.
170 Mortusewicz O, Schermelleh L, Walter J, Cardoso MC, Leonhardt H: Recruitment of DNA methyltransferase I to DNA repair sites. Proc Natl Acad Sci USA 2005;102: 8905-8909.

171 Hoeijmakers JH: Genome maintenance mechanisms for preventing cancer. Nature 2001;411:366-374.

172 Melnikova VO, Ananthaswamy HN: Cellular and molecular events leading to the development of skin cancer. Mutat Res 2005; 571:91-106.

173 Rass K, Reichrath J: UV damage and DNA repair in malignant melanoma and nonmelanoma skin cancer. Adv Exp Med Biol 2008;624:162-178.

174 Chan TA, Glockner S, Yi JM, Chen W, Van Neste L, Cope L, Herman JG, Velculescu V, Schuebel KE, Ahuja N, Baylin SB: Convergence of mutation and epigenetic alterations identifies common genes in cancer that predict for poor prognosis. PLoS Med 2008;5:e114. 